\title{
High Level of Energy and Protein Supplementation Effect on Feed Intake and Liveweight Gain of Bali Bulls Fed Elephant Grass ${ }^{\dagger}$
}

\author{
I Wayan Sulendre ${ }^{1}$, Marsetyo Marsetyo ${ }^{1, *}$, Muh Takdir ${ }^{2}$, Karen Harper ${ }^{3}$ \\ and Dennis Paulus Poppi ${ }^{3}$ \\ 1 Department of Animal Science, Tadulako University, Palu 94118, Indonesia; \\ wayanptkutd@gmail.com \\ 2 Agricultural Technology Assessment Center of Central Sulawesi, Sigi 94367, Indonesia; \\ dhirdhirag@gmail.com \\ 3 Schools of Agriculture and Food Sciences and Veterinary Science, University of Queensland, \\ Gatton 4343, Australia; karen.harper@uq.edu.au (K.H.); d.poppi@uq.edu.au (D.P.P.) \\ * Correspondence: marsetyomarsetyo@yahoo.co.uk \\ + Presented at the third International Tropical Agriculture Conference (TROPAG 2019), Brisbane, Australia, \\ 11-13 November 2019.
}

Published: 12 February 2020

\begin{abstract}
This research was carried out on-farm at Malonas village, Central Sulawesi, Indonesia to examine the effect of high level supplementation of by-products formulated for high ME and CP. Feed intake, faecal $\mathrm{pH}$ and liveweight gain of Bali bulls was observed. The basal diet was elephant grass, and supplements were rice bran (RB), cassava (C), palm kernel meal (PKM), gliricidia ( $G$ ) and urea. Fifty Bali bulls (weight $168 \pm 4.48 \mathrm{~kg}$ ) were housed in individual pens for 18 weeks (2 introductory and 16 experimental) and allocated into five treatments: $A=$ elephant grass (EG) ad libitum, B = EG offered at 1\%W/d, plus 2.5\%W/d mixed RB:G, (1:1), C = EG offered at 1\%W/d plus $2.5 \% \mathrm{~W} / \mathrm{d}$ mixed RB:PKM(1:1), D = EG offered at $1 \% \mathrm{~W} / \mathrm{d}$ plus $2.5 \% \mathrm{~W} / \mathrm{d}$ mixed C:G (1:1), E = EG offered at $1 \% \mathrm{~W} / \mathrm{d}$ plus $2.5 \% \mathrm{~W} / \mathrm{d}$ mixed C+ urea: PKM (1:1). Faecal pH was measured at weeks 3 , 9 and 15. Bali bulls fed B, C, D and E, consumed supplement at the rate of 2.15, 2.19, 2.09 and 2.29 $\% \mathrm{~W} / \mathrm{d}$, respectively. Total feed intake was $2.47,2.98,2.99,2.93,3.13 \% \mathrm{~W} / \mathrm{d}$, liveweight gain was 0.30 , $0.57,0.60,0.66,0.69 \mathrm{~g} / \mathrm{d}$ and faecal $\mathrm{pH}$ was $6.93,6.76,6.65,6.45,6.33$ for treatment $\mathrm{A}, \mathrm{B}, \mathrm{C}, \mathrm{D}$, and $\mathrm{E}$, respectively. Supplementation increased significantly $(P<0.05)$ total feed intake, liveweight gain, but reduced faecal $\mathrm{pH}$. The highest total feed intake and liveweight gain was achieved by treatment E. It is concluded that cassava can be provided at $1.15 \% \mathrm{~W} / \mathrm{d}$ in combination with protein supplement for high liveweight gain of Bali bulls.
\end{abstract}

Keywords: energy; protein; Bali bull 
Author Contributions: There were 5 authors involved in this study and publication. I.W.S. as a junior scientist did a ground activities to collect data daily, M.M., as a senior scientist, supervised field work, write the paper in English and data analysis, M.T., help junior scientist in collecting data and laboratory work, K.H. contributed in design experiment and edted the paper, D.P.P., edited and approved paper.

Funding: This study was funded by Th Australian Centre for Intenational Agricultural Research, project number LPS 2013/21.

Acknowledgments: The authors wish to thank to farmer at Malonas village for providing the bulls and pen facilities. They also thank to the undergraduate students at Department of Animal Science Tadulako University, who help in data collection at the pen.

Conflicts of Interest: The authors declare no conflict of interest.

(C) 2020 by the authors. Licensee MDPI, Basel, Switzerland. This article is an open access article distributed under the terms and conditions of the Creative Commons Attribution (CC BY) license (http://creativecommons.org/licenses/by/4.0/). 